\section{Elizabethkingia bruuniana Infections in Humans, Taiwan, 2005-2017}

\section{Jiun-Nong Lin, Chung-Hsu Lai, Chih-Hui Yang, Yi-Han Huang, Hsi-Hsun Lin}

\begin{abstract}
Author affiliations: E-Da Hospital, Kaohsiung, Taiwan (J.-N. Lin, C.-H. Lai, Y.-H. Huang); I-Shou University, Kaohsiung (J.-N. Lin, C.-H. Lai, Y.-H. Huang); Meiho University, Pingtung, Taiwan (C.-H. Yang); Taipei Veterans General Hospital, Taipei, Taiwan (H.-H. Lin)
\end{abstract}

DOI: https://doi.org/10.3201/eid2507.180768

Using $16 \mathrm{~S}$ rRNA and $r p o B$ gene sequencing, we identified 6 patients infected with Elizabethkingia bruuniana treated at E-Da Hospital (Kaohsiung, Taiwan) during 2005-2017. We describe patient characteristics and the molecular characteristics of the $E$. bruuniana isolates, including their MICs. Larger-scale studies are needed for more robust characterization of this pathogen.

$\mathrm{T}$ he Elizabethkingia genus comprises gram-negative, aerobic, nonmotile, nonspore-forming, nonfermenting rod-shaped bacteria (1). This genus previously comprised E. meningoseptica, E. miricola, and E. anophelis. In August 2017, Nicholson et al. proposed adding 3 new species, namely E. bruuniana, E. ursingii, and E. occulta, to this genus (1). However, little information exists about these species. In this study, we report the clinical characteristics and demographics of a group of patients with E. bruuniana infection in Taiwan and the molecular features of their $E$. bruuniana isolates.

We conducted this study at E-Da Hospital, a 1,000bed university-affiliated medical center in Kaohsiung, Taiwan; this study was approved by the institutional review board of the hospital (no. EMRP-106-105). We searched the hospital database to identify microbial cultures performed during January 2005-December 2017 that yielded Elizabethkingia. The isolates were initially identified by staff in the clinical microbiology laboratory using API/ID32 phenotyping kits or VITEK MS (both from bioMérieux, https://www.biomerieux.com). We reidentified these species as Elizabethkingia using both $16 \mathrm{~S}$ rRNA and $r p o B$ gene sequencing. The primers and methods we used for amplification and sequencing of the $16 \mathrm{~S}$ rRNA and rроB genes were described previously $(1,2)$. We compared the assembled 16S rRNA gene sequences with the nucleotide sequences of Elizabethkingia-type strains present in GenBank. We considered isolates with $\geq 99.5 \%$ similarity in the $16 \mathrm{~S}$ rRNA gene sequence members of the same species, as recommended in a previous study (3). We constructed a phylogenetic tree using the $r р о B$ genes of the isolates exhibiting $\geq 99.5 \% 16 \mathrm{~S}$ rRNA gene sequence identity with the E. bruuniana type strain G0146 ${ }^{\mathrm{T}}$. We calculated the average nucleotide identity using OrthoANI (4) and computed in silico DNA-DNA hybridization (DDH) using the Genome-to-Genome Distance Calculator (5), using the average nucleotide identity value of $\geq 95 \%$ and the DDH value of $\geq 70 \%$ separately as criteria for species delineation $(4,5)$. We sequenced the quinolone resistance-determining regions of DNA gyrase (gyrA and $\operatorname{gyr} B$ ) and topoisomerase IV (parC and parE) to look for mutations associated with resistance (Appendix Table, https://wwwnc.cdc.gov/EID/article/25/7/180768-App1.pdf).

For the 13-year period, we found 103 nonduplicate Elizabethkingia isolates in the database of the clinical microbiology laboratory. Among these, 8 isolates shared $\geq 99.5 \% 16 \mathrm{~S}$ rRNA gene sequence identity with E. bruuniana $\mathrm{G} 0146^{\mathrm{T}}$, and an rpoB gene-based phylogenetic analysis revealed that 6 of the 8 isolates were more closely related to E. bruuniana $\mathrm{G} 0146^{\mathrm{T}}$ (Appendix Figure $1)$. We previously published the complete whole-genome sequence of 1 of these 6 isolates, EM798-26 (GenBank accession no. CP023746) (6). Using 16S rRNA gene sequence analysis, we initially identified this isolate as $E$. miricola. Average nucleotide identity analysis demonstrated that EM798-26 and E. bruuniana $\mathrm{G} 0146^{\mathrm{T}}$ share $97.7 \%$ whole-genome similarity (Appendix Figure 2). Using in silico DDH analysis, we predicted a DDH value of $81.7 \%$ for EM798-26 and E. bruuniana G0146 ${ }^{\mathrm{T}}$ (Appendix Figure 3). These results support that EM798-26 and the other 5 isolates (EM20-50, EM455-89, EM828-05, EM863-68, and EM891-63) are E. bruuniana.

These 6 isolates were collected from 6 (4 male and 2 female) patients (Table) with a mean age of $71.7(\mathrm{SD} \pm 11)$ years. The sources of isolation included bronchoalveolar lavage fluid $(n=2)$, blood $(n=2)$, urine $(n=1)$, and the tip of the central venous catheter $(n=1)$. All infections were healthcare associated. Two patients had septic shock, and all patients had $\geq 1$ concurrent medical condition, such as hypertension, diabetes mellitus, or a malignancy. Antimicrobial therapy included piperacillin/tazobactam, trimethoprim/sulfamethoxazole, levofloxacin, or tigecycline, either singly or in combination. None of the patients died of E. bruuniana infection.

Most E. bruuniana isolates were resistant to $\beta$-lactams, $\beta$-lactam and lactamase inhibitors, carbapenems, aminoglycosides, and trimethoprim/sulfamethoxazole (Table). All isolates were susceptible to minocycline, $4(67 \%)$ to tigecycline and levofloxacin, and $2(33 \%)$ to ciprofloxacin. The antimicrobial susceptibility patterns we found are similar to those of other Elizabethkingia spp. identified 
Table. Characteristics of patients infected with Elizabethkingia bruuniana, Taiwan, 2005-2017, and antimicrobial susceptibility of the E. bruuniana isolates*

\begin{tabular}{|c|c|c|c|c|c|c|}
\hline \multirow[b]{2}{*}{ Category } & \multicolumn{6}{|c|}{ Patient no./isolate no. } \\
\hline & No. 1/EM20-50 & No. 2/EM455-89 & No. 3/EM798-26 & No. 4/EM828-05 & No. 5/EM863-68 & No. 6/EM891-63 \\
\hline \multicolumn{7}{|c|}{ Patient characteristics } \\
\hline Year of illness & 2005 & 2011 & 2015 & 2016 & 2016 & 2017 \\
\hline Age, $y / \operatorname{sex}$ & $67 / F$ & $62 / F$ & $81 / \mathrm{M}$ & $60 / \mathrm{M}$ & $88 / \mathrm{M}$ & $72 / \mathrm{M}$ \\
\hline $\begin{array}{l}\text { Site of microbe } \\
\text { isolation }\end{array}$ & Urine & CVC tip & Blood & Blood & BAL fluid & BAL fluid \\
\hline $\begin{array}{l}\text { Clinical } \\
\text { manifestations }\end{array}$ & $\begin{array}{l}\text { Urinary tract } \\
\text { infection }\end{array}$ & Septic shock & $\begin{array}{c}\text { Primary } \\
\text { bacteremia }\end{array}$ & $\begin{array}{c}\text { Primary } \\
\text { bacteremia }\end{array}$ & Pneumonia & $\begin{array}{l}\text { Pneumonia, } \\
\text { septic shock }\end{array}$ \\
\hline $\begin{array}{l}\text { Underlying } \\
\text { conditions }\end{array}$ & $\begin{array}{l}\text { Cervical cancer, } \\
\text { hypertension }\end{array}$ & $\begin{array}{c}\text { Maxillary } \\
\text { osteosarcoma, } \\
\text { hypothyroidism, } \\
\text { hypertension }\end{array}$ & $\begin{array}{l}\text { Lymphoma, } \\
\text { chronic kidney } \\
\text { disease }\end{array}$ & $\begin{array}{c}\text { Brain } \\
\text { meningioma, } \\
\text { stroke, } \\
\text { hypertension }\end{array}$ & $\begin{array}{l}\text { Liver cirrhosis, } \\
\text { hypertension, } \\
\text { CHF }\end{array}$ & $\begin{array}{c}\text { Esophageal } \\
\text { cancer, diabetes } \\
\text { mellitus, } \\
\text { hypertension }\end{array}$ \\
\hline Treatment & TMP/SMX & TZP & Levofloxacin & TZP, levofloxacin & Levofloxacin & $\begin{array}{l}\text { Tigecycline, } \\
\text { levofloxacin }\end{array}$ \\
\hline Outcome & Survived & Survived & Survived & Survived & Survived & Survived \\
\hline \multicolumn{7}{|l|}{$\mathrm{MIC}, \mathrm{mg} / \mathrm{L} \dagger$} \\
\hline Piperacillin & 64 & 64 & $>64$ & 64 & $>64$ & 64 \\
\hline TZP & $32 / 4$ & $>128 / 4$ & $32 / 4$ & $32 / 4$ & $64 / 4$ & $128 / 4$ \\
\hline Ceftazidime & $>16$ & $>16$ & $>16$ & $>16$ & $>16$ & $>16$ \\
\hline Cefepime & $>32$ & $>32$ & $>32$ & $>32$ & $>32$ & $>32$ \\
\hline Ceftriaxone & $>32$ & $>32$ & $>32$ & $>32$ & $>32$ & $>32$ \\
\hline Aztreonam & $>16$ & $>16$ & $>16$ & $>16$ & $>16$ & $>16$ \\
\hline Imipenem & $>8$ & $>8$ & $>8$ & $>8$ & $>8$ & $>8$ \\
\hline Meropenem & $>8$ & $>8$ & $>8$ & $>8$ & $>8$ & $>8$ \\
\hline Gentamicin & 8 & 8 & 4 & 8 & 4 & 8 \\
\hline Tobramycin & $>8$ & $>8$ & $>8$ & $>8$ & $>8$ & $>8$ \\
\hline Amikacin & $<8$ & 32 & 16 & $>32$ & 16 & 32 \\
\hline Tetracycline & $>8$ & $>8$ & $>8$ & $>8$ & $>8$ & $>8$ \\
\hline Minocycline & $<1$ & $<1$ & $<1$ & 4 & $<1$ & $<1$ \\
\hline Tigecycline & $<1$ & 8 & 2 & 4 & $<1$ & $<1$ \\
\hline Ciprofloxacin & 1 & 2 & 2 & $>2$ & 2 & 1 \\
\hline Levofloxacin & $<1$ & 8 & $<1$ & $>8$ & $<1$ & $<1$ \\
\hline TMP/SMX & $>4 / 76$ & $>4 / 76$ & $>4 / 76$ & $>4 / 76$ & $>4 / 76$ & $>4 / 76$ \\
\hline
\end{tabular}

in previous studies $(7-10)$. For example, reports from the United States, Hong Kong, and South Korea have revealed that E. anophelis and E. meningoseptica were frequently resistant to most $\beta$-lactams, including ceftazidime, ceftriaxone, and imipenem, but showed variable susceptibility to piperacillin/tazobactam, cefepime, ciprofloxacin, and levofloxacin (7-10).

To investigate the association between target gene mutations and fluoroquinolone resistance, we examined the mutations present in quinolone resistance-determining regions in these 6 isolates. We did not find nonsynonymous substitutions in the quinolone resistance-determining regions of $g y r A, \operatorname{gyr} B, \operatorname{par} C$, and $\operatorname{parE}$, which suggests that mutations in these genes are not the cause of fluoroquinolone resistance.

In summary, our study demonstrates the clinical manifestations of E. bruuniana infection and the molecular characteristics of the pathogen. Because cases in our study were limited in number, further large-scale studies are necessary to investigate the antimicrobial susceptibility patterns of E. bruuniana and elucidate the clinical characteristics and treatment of $E$. bruuniana infection.
This work was supported by grants from E-Da Hospital (no. EDAHP106007) and the Ministry of Science and Technology, Taiwan (no. 106-2314-B-214-009-MY2).

\section{About the Author}

Dr. Jiun-Nong Lin is an associate professor at the School of Medicine, College of Medicine, I-Shou University, Kaohsiung, Taiwan. His research interests include infectious diseases and clinical microbiology.

\section{References}

1. Nicholson AC, Gulvik CA, Whitney AM, Humrighouse BW, Graziano J, Emery B, et al. Revisiting the taxonomy of the genus Elizabethkingia using whole-genome sequencing, optical mapping, and MALDI-TOF, along with proposal of three novel

Elizabethkingia species: Elizabethkingia bruuniana sp. nov., Elizabethkingia ursingii sp. nov., and Elizabethkingia occulta sp. nov. Antonie van Leeuwenhoek. 2018;111:55-72. http://dx.doi.org/10.1007/s10482-017-0926-3

2. Lin JN, Lai CH, Yang CH, Huang YH, Lin HF, Lin HH. Comparison of four automated microbiology systems with $16 \mathrm{~S}$ rRNA gene sequencing for identification of Chryseobacterium and Elizabethkingia species. Sci Rep. 2017;7:13824. 
http://dx.doi.org/10.1038/s41598-017-14244-9

3. Janda JM, Abbott SL. 16S rRNA gene sequencing for bacterial identification in the diagnostic laboratory: pluses, perils, and pitfalls. J Clin Microbiol. 2007;45:2761-4. http://dx.doi.org/ 10.1128/JCM.01228-07

4. Lee I, Ouk Kim Y, Park SC, Chun J. OrthoANI: an improved algorithm and software for calculating average nucleotide identity. Int J Syst Evol Microbiol. 2016;66:1100-3. http://dx.doi.org/10.1099/ijsem.0.000760

5. Meier-Kolthoff JP, Auch AF, Klenk H-P, Göker M. Genome sequence-based species delimitation with confidence intervals and improved distance functions. BMC Bioinformatics. 2013;14:60. http://dx.doi.org/10.1186/1471-2105-14-60

6. Lin JN, Lai CH, Yang CH, Huang YH, Lin HH. Complete genome sequence of Elizabethkingia miricola strain EM798-26 isolated from the blood of a cancer patient. Genome Announc. 2018;6:e01408-17. http://dx.doi.org/10.1128/genomeA.01408-17

7. Hsu MS, Liao CH, Huang YT, Liu CY, Yang CJ, Kao KL, et al. Clinical features, antimicrobial susceptibilities, and outcomes of Elizabethkingia meningoseptica (Chryseobacterium meningosepticum) bacteremia at a medical center in Taiwan, 1999-2006. Eur J Clin Microbiol Infect Dis. 2011;30:1271-8. http://dx.doi.org/10.1007/s10096-011-1223-0

8. Lau SK, Chow WN, Foo CH, Curreem SO, Lo GC, Teng JL, et al. Elizabethkingia anophelis bacteremia is associated with clinically significant infections and high mortality. Sci Rep. 2016;6:26045. http://dx.doi.org/10.1038/srep26045

9. Perrin A, Larsonneur E, Nicholson AC, Edwards DJ, Gundlach KM, Whitney AM, et al. Evolutionary dynamics and genomic features of the Elizabethkingia anophelis 2015 to 2016 Wisconsin outbreak strain. Nat Commun. 2017;8:15483. http://dx.doi.org/10.1038/ncomms15483

10. Han MS, Kim H, Lee Y, Kim M, Ku NS, Choi JY, et al. Relative prevalence and antimicrobial susceptibility of clinical isolates of Elizabethkingia species based on 16S rRNA gene sequencing. J Clin Microbiol. 2017;55:274-80. http://dx.doi.org/ 10.1128/JCM.01637-16

Address for correspondence: Jiun-Nong Lin, E-Da Hospital, Division of Infectious Diseases, Department of Internal Medicine, No. 1, Yida Road, Jiaosu Village, Yanchao District, Kaohsiung 824, Taiwan; email: jinoli@kmu.edu.tw

\section{Human Enterovirus C105, China, 2017}

\author{
Maozhong Li, ${ }^{1}$ Tiegang Zhang, ${ }^{1}$ Cheng Gong, \\ Aihua Li, Ming Luo, Mei Dong, Fang Huang
}

Author affiliation: Beijing Center for Disease Prevention and Control, Beijing, China

${ }^{1}$ These authors contributed equally to this article.
DOI: https://doi.org/10.3201/eid2507.180874

We report a case of enterovirus C105 infection in an 11-year-old girl with lower respiratory tract symptoms that was identified through the Respiratory Virus Surveillance System, which covers 30 sentinel hospitals in all 16 districts of Beijing, China. The presence of this virus strain in China confirmed its geographically wide distribution.

$\mathrm{E}$ nteroviruses are small, nonenveloped RNA viruses that cause illnesses in humans ranging from mild to severe (1). Fifteen species of enterovirus are known, 7 of which are known to infect humans. These species include enterovirus $\mathrm{A}-\mathrm{D}$ and rhinovirus $\mathrm{A}-\mathrm{C}(1,2)$. The newly emerging genotype C105 (EV-C105) represents a novel monophyletic clade of enterovirus $C$; this strain was identified in 2010 in the Democratic Republic of the Congo (strain 34S) $(3,4)$. EV-C105 cases from Italy (Pavia/8376, Pavia/9095), Romania (ROM31), the United States (USA/OK/201419362), New Zealand (strains not available), and Burundi (BU77, BU5) have been identified and characterized, suggesting that the spread of EV-C105 could be wider than previously hypothesized (5). Here, we report a detected case of EV-C105 in an 11-year-old girl with lower respiratory tract symptoms in Beijing, China.

The Beijing Center for Disease Prevention and Control established the Respiratory Virus Surveillance System (RVSS) in 2014. The RVSS tracks patients with respiratory tract infections (RTIs) and pneumonia in 30 sentinel hospitals throughout Beijing. The RVSS is an active system, designed to alert for future outbreaks of respiratory infections. To study enterovirus infections, we tested 24,093 clinical specimens (nasopharyngeal swab, sputum, and alveolar lavage fluid) from patients with RTIs that were reported through RVSS during June 2014-December 2017. RVSS classifies persons $<14$ years of age as children and those $\geq 14$ years of age as adults. The ages of the reported patients ranged from 8 months to 93 years (median 33.5 years, mean 37.9 years).

We screened all samples using real-time PCR for influenza virus, parainfluenza virus types $1-4$, respiratory syncytial virus, coronaviruses (229E, NL63, HKU1, and OC43), metapneumovirus, adenovirus, bocavirus, and enteroviruses (6). Overall, $445(445 / 7,122 ; 6.2 \%)$ children and $276(276 / 16,971 ; 1.6 \%)$ adults were positive for enterovirus or other respiratory viruses.

We further genotyped enterovirus-positive samples with primers sequentially targeting the viral protein (VP) 1 region $(7,8)$. We obtained a 699-nt amplicon of EV-C105 from a nasopharyngeal swab sample collected at the time of a hospital visit (GenBank accession no. KX910099). The patient was an 11-year-old girl with no underlying disease who was brought to the outpatient clinic of the Beijing Children's 